\title{
ALIGNMENT AND THEORY IN CORPORATE REAL ESTATE ALIGNMENT MODELS
}

\author{
Christopher HEYWOOD $^{a^{*} \text {, Monique ARKESTEIJN }}{ }^{b}$ \\ a Faculty of Architecture, Building and Planning, University of Melbourne, Melbourne, Victoria 3010 , \\ Australia \\ ${ }^{b}$ Department of Management in the Built Environment, Faculty of Architecture and the Built Environ- \\ ment, Delft Technical University, Delft, The Netherlands
}

Received 18 March 2015; accepted 3 May 2016

\begin{abstract}
This paper deepens the understanding of Corporate Real Estate (CRE) alignment through a meta-study of twenty existing alignment models. A qualitative hermeneutic method interpreted the models and their articles. This holistic analysis found alignment to be more complex and pluralistic than the individual models assumed. Four dimensions operating simultaneously were evident - a multi-valent relationship, multiple alignment forms, multiple cognitive objects to align and alignment in multiple directions. Alignment theorisation had positive and negative aspects. Positive is that good science was evident and had improved over time. Negative is that model theorisation had occurred mostly in isolation and was constrained by simplifications required to make modelling tractable. The research makes a meta-theoretical contribution through a more complete theorisation of CRE alignment as a phenomenon. This addresses a disordered sense to prior theory thereby representing a major conceptual improvement. A new alignment model is not proposed; rather through developed understanding a basis is provided to examine alignment in both theorisation and practice.
\end{abstract}

KEYWORDS: Corporate real estate; Alignment; Theory; Meta study; Models

\section{INTRODUCTION}

A long-standing issue for corporate real estate management (CREM) is the relationship between corporate real estate (CRE) and organisational strategies to deliver organisational value. Over CREM's development numerous authors have addressed this and the following indicates that development. Veale (1989) is an early example and Nourse and Roulac (1993) is an important one shortly afterwards. A decade later Osgood Jr (2004) mapped it and another decade on Beckers et al. (2015) examined it in higher education CRE. Also, CRE executives are increasingly involved with aligning CRE and business strategies as a key part of their work (Osgood Jr 2009). However, examining the literature shows two things. First, surveys persistently show that large percentages of practitioners can say whether their CRE is aligned or not, for example, Bon and Luck (1998, 1999) and McDonagh and Nichols (2009). Second, the CRE literature ad-

\footnotetext{
* Corresponding author. E-mail: c.heywood@unimelb.edu.au
}

vances multiple possible explanations and models for this alignment. Even cursory inspection of the models shows considerable variety in what they include and what they say should be aligned. This indicates a somewhat disordered CRE alignment theory. It may also be that practitioners operate anywhere between blissful ignorance and highly competent practice that is at present poorly or imperfectly theorised.

The multiple approaches make it more likely that existing theory is imperfect and disordered meaning that a thorough, critical examination of CRE alignment theory is warranted - for its contribution to CRE alignment theory and as a platform for understanding alignment practice. Therefore, this paper examines the alignment models to better understand what they say about CRE alignment as a phenomenon and its theorisation. Thorough examination of the CRE alignment theory and models is rare. Indeed, a substantial critique of the CRE alignment models is that each is usually presented in isolation with little if any 
reference to previous modelling efforts. Four known examples of thorough alignment examination are de Jonge et al. (2009, 2008), Appel-Meulenbroek et al. (2010), Heywood (2011) and Arkesteijn et al. (2015). The first examined six models to overview and compare their components, the second examined eight models to adopt one to study Dutch aged care CRE. The third identified components evident in ten alignment models and the approaches, origins and alignment form within twenty two CRE alignment-related articles. The fourth classified fourteen models to study if they were able to determine if an alignment state is reached. This paper develops and supersedes part of the work of Heywood (2011) and de Jonge et al. (2009, 2008) and addresses two key questions:

- How can we now understand the nature of CRE alignment as a phenomenon?

- How is CRE alignment theorised?

Future papers are planned to develop Heywood's (2011) and de Jonge et al. (2009, 2008) analysis, including a paper on the models' components.

\section{METHODS}

This paper uses a meta-study of the CRE alignment literature to not just 'review' the literature to establish an empirical study's theoretical basis but uses the literature itself as data for analysis.

A qualitative, hermeneutic method was adopted as most appropriate for this task where interpretation and understanding (verstehen) of a 'text' is central (Patton 1990; Bleicher 1980). Potentially subjective interpretation is made objective by using methodological meta-theoretical rules provided by Bleicher (1980: 33-34) of which key rules are:

- Having an inherent interest in understanding where an intellectual interest in understanding for its own value drives the engagement. Understanding is the interpretation's highest motivator;

- Recognising that interpretation of 'meaningfull' objects (Bleicher 1980) such as texts, images, and social practices requires understanding the creation context in order to understand its meaning and the creators' intentions. Preunderstanding is necessary, meaning that creators and interpreters must belong to a common intellectual community - a 'universe of discourse'. Here, the authors as experienced CRE academics are in such a community; and

- The whole object being interpreted informs the parts which in turn informs the whole (the 'hermeneutic circle') (after Bleicher 1980 and Patton 1990).
Several interpretive approaches exist including Traditional and Hermeneutic ones (Mugeraurer 1995). Traditional interpretation is based on Platonic and Aristotelian understandings of, in the first case, ideal forms represented in human endeavours and in the second, based on things made by human agency. This means that interpretation examines a human-created thing in light of its origins or creation, its forms, materials, and context, and its ethical and intellectual impulse back to social, natural and perhaps sacred reality' (Mugeraurer 1995: xxi). Hermeneutic interpretation (to distinguish it from the method outlined above) aims to "clarify how understanding takes place' (Mugeraurer 1995: xxvi). As such it may not produce new work or theory. Rather it focuses on things closest to us that may be taken for granted and which have had their meanings obscured by time, historical shifts or forgetfulness. Tracing these things back to their origins aims to reveal obscured meanings, to see them differently from before and in doing so to enrich our experiences and actions (after Mugeraurer 1995: 118-119).

This paper and the larger research project from which it is drawn used both approaches. Traditional interpretation endeavours to uncover the reality evident in multiple attempts to model CRE alignment. Hermeneutic interpretation is used to reveal the meaning of things close to the CRE field - alignment models and theory - and help the field to see them differently, obscured as they are in familiarity and the multiple attempts to theorise alignment. Also, this interpretation shows how understanding of alignment has been created through its theorisation.

\section{Specific methods in this study}

To identify objects for analysis one author's Endnote database containing approximately 1800 references compiled since 1998 was searched using one or more of the following terms - CRE strategy, alignment, and business or corporate strategy. These were thought to represent the phenomenon under investigation. Since the original search additional alignment articles have been published. These were added to the database and the interpretation. This produced thirty nine articles ${ }^{1}$ with associated 'meaning-full' objects. First inspection

\footnotetext{
${ }^{1}$ Please note that 'articles' is used throughout this paper to denote book chapters, reports, conference papers and journal papers. It was decided not to use 'texts' for these things because interpretive methods can denote anything subject to interpretation as a 'text' - movies, buildings, social practices as well as documents.
} 
showed that not all objects were comparable or, indeed, models aligning CRE and organisational strategy. To produce comparable objects the meaning-full object (with one exception) was taken to be a diagrammatic, real estate-based model and an associated textual material in an 'article'. On that basis the following were excluded:

- Models for aligning CREM where internal CREM function action improves CREM performance;

- Facilities management (FM) service-focussed models. FM branded models were included but only where they included significant real estate elements; and

- Articles on single CRE or CREM factors to align like location or workplace.

The exception was Levy and Hook Jr (1987a, 1987b). This was included despite the absence of a model because it is one of the earliest theorisations of the relationship between CRE and organisational strategies making it useful in plotting alignment thinking's trajectory. Of the remaining objects some were clearly called alignment models (an explicit alignment model). Some models could have been used for alignment through reference to alignment synonyms. Some would be useful in alignment without explicitly mentioning alignment but were captured through the search terms. The last two are non-explicit alignment models. Some models were in several articles by the same author(s) and were, consequently, treated as one. Another author presented two models sufficiently different to be considered separately.

Multiple passes through the articles were required to fully elicit their meaning. In the first pass memos that included the models' diagrams were made précising the articles (Miles, Huberman 1994). These memos were augmented in further iterations with thematic, textual and graphical analysis as a form of content analysis (Miles, Huberman 1994; Carney 1972). Thematic analysis was used to reveal origins, scientific bases and forms of alignment. Textual analysis was used to support and document the interpretation generally. Graphical analysis of the diagrams was also used to identify structures within the models.

These analyses were tabulated (Miles, Huberman 1994) to check and refine the interpretation. These tabulations are the basis of the paper's tables.

The deep hermeneutic analysis resulted in two bases of meaning emerging being:

1. The nature of the phenomenon in the models how it is defined, its theoretical bases and how it exists in the models (Tables 1 to 5); and
2. The models' theorisation by way of origins and scientific basis (Table 6).

As a whole, they represent the understanding (verstehen) now available as to what is meant by alignment in the models and how alignment is theorised.

\section{UNDERSTANDING THE NATURE OF CRE ALIGNMENT}

Because this paper aims to develop understanding through analysing the alignment models we do not propose to offer 'our' alignment definition at this juncture. Rather, the meaning-full objects are allowed to 'speak' for themselves through analysis (Table 1).

Very few articles (2 of 20) specifically define alignment. Then and Tan (2013) assemble several quotes from Kaplan and Norton (2006) to infer a definition because Kaplan and Norton do not actually provide one. Englert (2001) provides an important definition highlighting the vertical alignment between organisational and CRE strategies, and horizontal alignment across the business units. Another two rely on Dewulf's et al. (2000) CREM definition that includes alignment in CREM's raison d'etre.

One reason for no definition can be attributed to the article not being branded as 'alignment'. In the absence of definitions three things happen:

1. Reliance on dictionary definitions about bringing things into agreement, or there being harmony or consistency for things that might otherwise differ (after Shorter Oxford Dictionary); or

2. Reliance is placed on general understanding of what is meant in the field. As will be shown, multifarious meanings are possible (Table 1); or

3. Other terms which constitute 'alignment synonyms' are used to denote the relationship between CRE and organisational strategies (Table 1).

Interpretive examination of the words for the relationship reveals, based on their semantic qualities, a hierarchy of meaning. This interpretation relied on one author's previous experience with semantic analysis (Heywood 2007), a long-standing interest in word etymologies (origins and meanings) and, where these were inconclusive, reference to the Shorter Oxford Dictionary. This revealed a multi-valent relationship (that is, multi-valued or strength) with a hierarchy of significance within the relationship (Table 1). 
Table 1. 'Alignment' words and their relationships' semantic quality

\begin{tabular}{|c|c|c|}
\hline Words & Relationship's semantic quality and valency & Articles \\
\hline Linked & A relationship exists between the two concepts & $\mathrm{A}, \mathrm{B}, \mathrm{D}, \mathrm{E}, \mathrm{L}, \mathrm{M}, \mathrm{P}$ \\
\hline Informed & An awareness-based relationship & $\mathrm{D}$ \\
\hline Follow, Derived & A derivation-based relationship & $\mathrm{A}, \mathrm{B}, \mathrm{M}, \mathrm{T}$ \\
\hline $\begin{array}{l}\text { Coherent, Align, Moving (together), Synchro- } \\
\text { nised }\end{array}$ & A consistency-based relationship & $\begin{array}{l}\text { A, F, H, I, K, O, P, Q, R, } \\
\text { S, T }\end{array}$ \\
\hline Incorporate, Integrated & An integration-based relationship & $\mathrm{C}, \mathrm{F}, \mathrm{G}, \mathrm{I}, \mathrm{S}, \mathrm{T}$ \\
\hline Align, Moving (together), Synchronised & A movement-based relationship & $\mathrm{I}, \mathrm{K}, \mathrm{O}, \mathrm{P}, \mathrm{R}, \mathrm{S}, \mathrm{Q}, \mathrm{T}$ \\
\hline $\begin{array}{l}\text { Correctly applied, Value-maximising, Match/ } \\
\text { Mismatch, Appropriate, Conflict absence }\end{array}$ & An assessment-based relationship & $\mathrm{E}, \mathrm{H}, \mathrm{J}, \mathrm{O}, \mathrm{P}, \mathrm{Q}, \mathrm{T}$ \\
\hline $\begin{array}{l}\text { Effective, Optimal (CRE solutions, contribu- } \\
\text { tion, balance), Value-adding }\end{array}$ & A usefulness-based relationship & A, D, H, J, L, O, P, Q, S \\
\hline $\begin{array}{l}\text { Support, Value-maximising, Value-creating, } \\
\text { Value-adding, Reinforce, Plays a role, Enable }\end{array}$ & A strengthening-based relationship & $\begin{array}{l}\text { E, H, I, J, K, L, M, N, O, } \\
\text { P, Q, S }\end{array}$ \\
\hline
\end{tabular}

Legend: A - Levy and Hook Jr (1987a, 1987b); B - Nourse and Roulac (1993); C - Weatherhead (1997, Ch. 4); D - White (1998); E - O'Mara (1999); F - Englert (2001); G - Roulac (2001); H - Edwards and Ellison (2003); I - Osgood Jr (2004, 2009); J - Then (2005); K - Wills (2005); L - Lindholm et al. (2006), Lindholm and Levainen (2006), Gibler and Lindholm (2012); M - Scheffer et al. (2006); N - Singer et al. (2007); O - de Vries et al. (2008); P - de Jonge et al. (2008, 2009), den Heijer (2011), Van der Zwart et al. (2009); Q - Appel-Meulenbroek et al. (2010); R - Haynes (2008, 2012); S - Haynes and Nunnington (2010); T - Then and Tan (2013), Then et al. (2014).

NB. Words appear on more than one occasion because they have multiple semantic qualities.

Plotting the analysis this way shows a semantic progression from lesser to stronger and more valuable connection levels within the synonyms' multiple value senses. At the lower end there is 'just' having a relationship and two derivation-related links where corporate strategy 'informs' CRE strategy allowing the latter to be 'derived' from the former. At the upper end there is a utility relationship where the CRE strategy is 'useful' to, and even better, actually 'strengthens' corporate strategy. Between are words to do with the relationship's closeness, that is, the two are 'consistent', 'integrated', and have 'moved' closer together. To ascertain the degree of proximity 'assessment' is required. Outcomes of that assessment are likely to lead to conclusions about the utility of CRE strategy.

There is a sense in some articles and models that just 'deriving' CRE strategy from business strategy is enough. While this needs to be done, this does not fully capture Weatherhead's (1997) inference of a strengthening quality through corporate strategy that includes (corporate) real estate. This two-way relationship is important in achieving strategic CREM and is of a higher order than just deriving CRE strategy. When verbalising CRE strategy it would be better to use higher level words. It was evident that patterns of word usage did not vary much over time though recent years has seen 'value-added' quite widely used.

It is also possible to develop understanding of the nature of CRE alignment by examining the authors' theory in locating their model (Table 2). Various underlying theorisations were identified:

- Strategic management with two additional sub-types:

- Strategic alignment theory; and

- Organisational performance assessment;

- Political science - institutional theory;

- Real estate management with several subtypes:

- Specific CREM;

- Facilities Management; and

- Workplace management - productivity and design.

This analysis showed, as expected, CRE alignment to largely be at the nexus of real estate and strategic management theories. Where underlying theories are not noted, these articles tend to be early ones created by practitioners as advice, or as practical techniques. Most authors refer to or rely on both fields in locating their models (even if not citing specific authorities). Where specific texts are cited, Porter's competitiveness and Hamel and Prahalad's (1994) core competencies work often represented strategic management theory, though Mintzberg et al. (1998) also featured. Kaplan and Norton's (2006) strategic alignment theory was also prevalent, as might be expected. For real estate management theory, Nourse and Roulac (1993), and to a lesser extent O'Mara (1999) are the most relied-on texts. Dutch articles also usually reference de Jonge (1996) as their real estate management basis. The political science theorisation was unusual but the authors argue for this 
Table 2. Alignment models' theoretical bases

\begin{tabular}{|c|c|c|c|}
\hline & \multicolumn{3}{|l|}{ Underlying theories } \\
\hline & Strategic management & Political science & Real estate management \\
\hline $\begin{array}{l}\text { Levy and Hook Jr } \\
(1987 \mathrm{a}, 1987 \mathrm{~b})\end{array}$ & Business strategic planning. & & \\
\hline $\begin{array}{l}\text { Nourse and Roulac } \\
\text { (1993) }\end{array}$ & $\begin{array}{l}\text { Strategic management, for instance, } \\
\text { Porter (1980, 1985), Mintzberg } \\
\text { (1990), Tregoe and Zimmerman } \\
(1980) \text {. }\end{array}$ & & \\
\hline $\begin{array}{l}\text { Weatherhead } \\
\text { (1997, Ch. 4) }\end{array}$ & $\begin{array}{l}\text { Strategic management (Porter 1980, } \\
\text { 1985; Hamel, Prahalad 1994). }\end{array}$ & & \\
\hline White (1998) & Not given. & & \\
\hline O’Mara (1999) & $\begin{array}{l}\text { Strategic management - (Porter } \\
1980,1985) .\end{array}$ & & CREM (various**). \\
\hline Englert (2001) & $\begin{array}{l}\text { (Porter 1985; Henderson, } \\
\text { Venkataraman 1991, 1993). }\end{array}$ & & \\
\hline Roulac (2001) & $\begin{array}{l}\text { Strategic management theory } \\
\text { (Porter 1985). }\end{array}$ & & $\begin{array}{l}\text { CREM strategy, primarily } \\
\text { Nourse and Roulac (1993) }\end{array}$ \\
\hline $\begin{array}{l}\text { Edwards and Ellison } \\
\text { (2003) }\end{array}$ & & $\begin{array}{l}\text { Political science and espe- } \\
\text { cially an institutionalist } \\
\text { perspective based on Os- } \\
\text { trom (1976), Kiser and Os- } \\
\text { trom (1982), Ostrom (1986), } \\
\text { Oakerson }(1982,1984) .\end{array}$ & \\
\hline $\begin{array}{l}\text { Osgood Jr (2004, } \\
2009)\end{array}$ & $\begin{array}{l}\text { Strategic management theory - } \\
\text { (Porter 1980, 1985). }\end{array}$ & & \\
\hline Then (2005) & & & Various FM and CREM. \\
\hline Wills (2005) & & & CREM \\
\hline $\begin{array}{l}\text { Lindholm et al. } \\
\text { (2006), Lindholm } \\
\text { and Levainen } \\
\text { (2006), Gibler and } \\
\text { Lindholm (2012) }\end{array}$ & $\begin{array}{l}\text { Strategic management and business } \\
\text { performance - alignment theory } \\
\text { (Kaplan, Norton 2006). }\end{array}$ & & CREM (de Jonge 1996). \\
\hline Scheffer et al. (2006) & & & $\begin{array}{l}\text { CREM theory - (Nourse, } \\
\text { Roulac 1993; de Jonge } \\
\text { 1996). }\end{array}$ \\
\hline Singer et al. (2007) & & & $\begin{array}{l}\text { (Porter 1980, 1985, } \\
\text { Porter 1996; O’Mara 1999; } \\
\text { Nourse, Roulac 1993). }\end{array}$ \\
\hline de Vries et al. (2008) & $\begin{array}{l}\text { Management theory - alignment theo- } \\
\text { ry (Kaplan, Norton 1996, 2001). }\end{array}$ & & RE management (various). \\
\hline $\begin{array}{l}\text { de Jonge et al. }(2008 \text {, } \\
\text { 2009), den Heijer } \\
\text { (2011), Van der Zwart } \\
\text { et al. (2009) }\end{array}$ & $\begin{array}{l}\text { Strategic management (Mintzberg } \\
\text { et al. 1998; Idenburg } 1993 \text { and various } \\
\text { others) }\end{array}$ & & $\begin{array}{l}\text { RE management (various, } \\
\text { for example O'Mara 1999; } \\
\text { Nourse, Roulac 1993; Os- } \\
\text { good Jr 2004). }\end{array}$ \\
\hline $\begin{array}{l}\text { Appel-Meulenbroek } \\
\text { et al. (2010) }\end{array}$ & $\begin{array}{l}\text { Strategic management theory } \\
\text { (Mintzberg et al. 1998/2007; Tregoe, } \\
\text { Zimmerman 1980; Kaplan, Norton } \\
\text { 2000; Porter 1996; Swayne et al. } \\
\text { 2006). }\end{array}$ & & $\begin{array}{l}\text { CREM theory, principally } \\
\text { Nourse and Roulac (1993). }\end{array}$ \\
\hline Haynes $(2008,2012)$ & $\begin{array}{l}\text { Strategic management theory } \\
\text { (Porter 1980). }\end{array}$ & & $\begin{array}{l}\text { Workplace productivity } \\
\text { and design (various), FM. }\end{array}$ \\
\hline $\begin{array}{l}\text { Haynes and Nun- } \\
\text { nington }(2010)\end{array}$ & $\begin{array}{l}\text { Strategic management theory } \\
\text { (various). Alignment (Kaplan, } \\
\text { Norton 2006). }\end{array}$ & & $\begin{array}{l}\text { CREM theory (various). } \\
\text { Workplace productivity and } \\
\text { design (various). }\end{array}$ \\
\hline $\begin{array}{l}\text { Then and Tan (2013), } \\
\text { Then et al. (2014) }\end{array}$ & $\begin{array}{l}\text { Alignment theory - Kaplan and } \\
\text { Norton (2006) } \\
\text { Strategic management. }\end{array}$ & & \\
\hline
\end{tabular}


because they want their student readers to engage with an institutional explanation of real estate.

Some articles limit their underlying theorisation to real estate and facilities management. Doing this risks 'real estate myopia' where real estate (operational) concerns of, for example, tenure forms and transactions, property value, real estate costs, and workplace design dominate thinking rather than the strategic impact of the real estate and its management. For CREM to be a full business management discipline rather than a real estate one (a subtle but important distinction) then $\mathrm{CRE}$ alignment needs to be in the strategic management area, where many models locate it.

\section{UNDERSTANDING FORMS OF ALIGNMENT}

When trying to understand alignment's existence within the models it was evident that different things are meant. The next three sections examine this. First, is understanding alignment's forms or modes of existence in the models. Conceptually, the business alignment literature identifies three alignment forms - two noun forms (a state of being, and a strategy or plan) and a verb (a set of actions that make up a process) (Kaplan, Norton 2006; Labovitz, Rosansky 1997). These provided an initial thematic framework with which to analyse the articles. Additionally, interpretation needs to be open to the presence of alternative or additional themes, which resulted in one emergent one. The four forms were:

- A defined 'strategy' or 'plan' for alignment which can be inferred as existing as a document making it some type of artefact;

- A 'process' which is defined as a set of actions or the management tasks to achieve greater alignment;

- A 'state' which is the degree of alignment, now or in the future. It refers to how 'much' alignment is achieved; and

- 'Behaviour' which is having a strategic mind-set as an emergent form suggested by O'Mara (1999) and was informed by Joroff's et al. (1993) 'Business strategist' inferring the importance of strategic-oriented behaviour. While a mind-set is a cognitive state, having it constitutes behaviour, that could prove instrumental in achieving strategic outcomes when faced with a flood of operational and tactical pressures.

The analysis then progressed to understanding how the authors conceptualised alignment's form of existence in the 'articles' (Table 3). Most models included multiple forms with each form present to different degrees as follows:

1. The principal concept in the article's model and text ' $\mathbf{\square}$ '. This allows for other forms to be included to lesser degrees;

2. Included in the article (' $\square$ '), typically as one of several forms present in comparable degrees; and

3. Implied from the model or, more usually, the accompanying text (' $\square$ '). This usually required an interpretive act based on knowing the pre-existing alignment forms, or the interpretation-developed emerging forms, like 'behaviour'.

The earliest form and present over time is an aligned plan (artefact) (7 of 20 models $-35 \%$ ). This is consistent with strategic planning - having a plan for alignment or showing how alignment is achieved as a useful basis for strategic planning ${ }^{2}$. The strongest presence is alignment as a process in 18 models (90\%); in 11 articles (55\%) this is the principal concept. The state form of alignment was also clearly evident - 16 models $(80 \%)$ - though interpretation was usually required to reveal it. Given that applying a process produces change in alignment states it is logical that these two forms were frequently found together.

Please note that alignment plans may include processes to follow and statements about current and future alignment states. However, it is important to distinguish artefact forms from others because it is possible that these other forms may be undocumented residing only in CREM's mind. A process may only be evident in hindsight and especially so without coherent theory to guide the process. A state may only be evident from examining the portfolio, its strategies, and the current and future demands on the portfolio. It is thought, from the evidence available, that these mental forms are what CREM executives rely on in surveys of alignment.

Haynes' $(2012,2008)$ model could not be placed in any of these forms. Instead it appeared to consist of several things to be attended to in alignment, or places where alignment effects could be found.

\footnotetext{
$\overline{2}$ Different interpretations exist for what 'strategic planning' and 'strategic management' mean. While often taken to be the same thing, business tends to use the former and the academy the latter. Sometimes strategic planning means only strategy formation, not the implementation and evaluation included in strategic management definitions (David 2013).
} 


\begin{tabular}{|c|c|c|c|c|c|c|c|c|c|c|c|c|c|c|c|c|c|c|c|c|c|c|}
\hline & 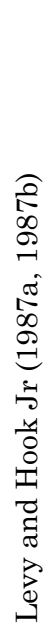 & 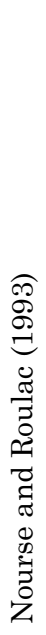 & 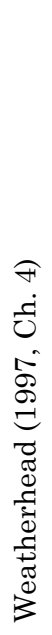 & 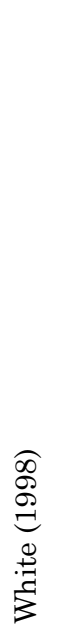 & 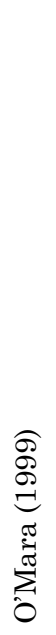 & 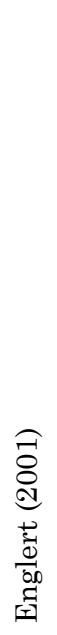 & 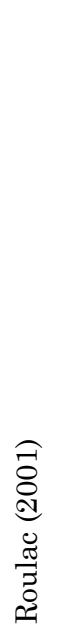 & 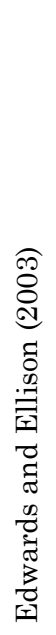 & 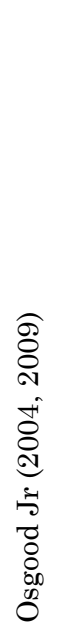 & 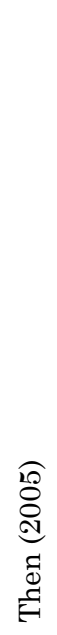 & 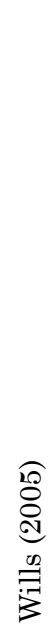 & 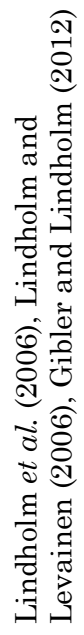 & 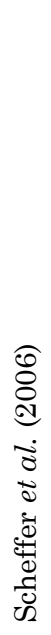 & 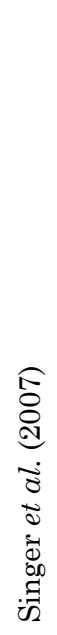 & 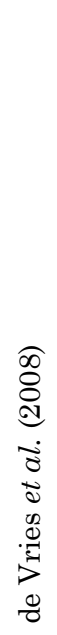 & 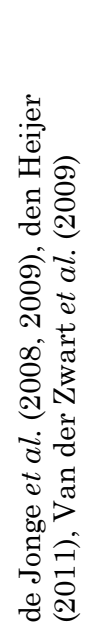 & 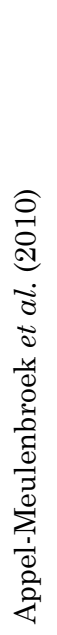 & 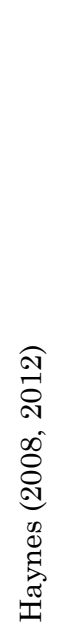 & 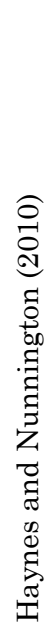 & 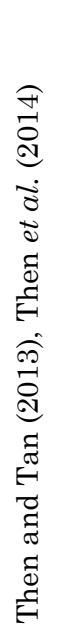 & 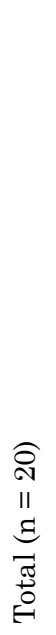 & $d^{0}$ \\
\hline \multicolumn{23}{|c|}{ Form of alignment $(n=20)$} \\
\hline Artefact (a plan) & ם & & & $\square$ & & & & & $\square$ & $\square$ & $\square$ & & & & & $\square$ & & & & $\square$ & 7 & 35 \\
\hline Process & $\square$ & ם & 口 & $\square$ & $\square$ & $\boldsymbol{\square}$ & 口 & $\boldsymbol{\square}$ & $\boldsymbol{\square}$ & 口 & $\square$ & 口 & $\square$ & $\square$ & & ם & 口 & & $\square$ & 口 & 18 & 90 \\
\hline State & & $\square$ & $\square$ & & $\square$ & $\square$ & $\square$ & $\square$ & $\square$ & $\square$ & $\square$ & $\square$ & ם & & $\square$ & $\square$ & $\square$ & & $\square$ & $\square$ & 16 & 80 \\
\hline Behaviour & & $\square$ & $\square$ & & $\square$ & $\square$ & & & & & & & & & & & 口 & & $\square$ & & 6 & 30 \\
\hline
\end{tabular}

Legend: Form of alignment.

The models combining multiple alignment forms suggest two distinctly different CRE alignment types. First is a 'process-based' type where a model provides a series of steps a plan for greater alignment and/or a state of greater alignment for individual CRE objects or the portfolio as a whole. A process is useful and constitutes an explanation of what is otherwise hidden behind the professional expertise that is prevalent in current CREM practice. The second type is 'behaviour-based' with six models including this type. Here, having a strategic mindset at every opportunity is important for assessing strategic potential - positive and negative - of the tactical and operational actions. Behaviour is, in all six models, combined with process and could also produce more aligned states. This type offers a more fluid alignment approach contrasting with what could be more mechanistic processes and plans.

\section{UNDERSTANDING THE COGNITIVE OBJECTS BEING ALIGNED}

In understanding CRE alignment it is important to know what is being aligned because part of CRE alignment theory's evident disorder is attributable to the various cognitive objects ${ }^{3}$ that the articles say

\footnotetext{
3 This paper uses 'cognitive objects' as the concepts that are the focus of knowledge production efforts. 'Objects' recognises that these have a formal existence, albeit one that is a product of, or contained within, mental (cognitive) efforts (Whitley 2000).
}

should be aligned. The analysis showed six distinct cognitive objects - three business-related ones and three real estate-related ones (Table 4). Because various words were used, this analysis is thematically based. This resulted in related terms and concepts like, for instance, Business drivers (Nourse, Roulac 1993) being thematically linked to Business strategy. Similarly, the CRE cognitive object is linked to physical artefacts or operating decisions that result in such artefacts. It was evident that a hierarchy of cognitive objects existed - sequentially in that some objects are aligned first, then others. Similarly, some objects, like Business needs, are more reactive focussing on current demand whereas Business strategy alignment attends to future changes in CRE's organisational demand. This thinking underpins Table 4's ordering. One thing not found was the differentiation between 'espoused CRE strategy' and 'CRE strategy in-use' observed by Beckers et al. (2015). Theirs is an interesting finding suggesting different approaches to strategizing as identified by Mintzberg et al. (1998) and Idenburg (1993).

Table 4. Business and CRE-related cognitive objects in the alignment models

\begin{tabular}{ll}
\hline Business-related objects & CRE-related objects \\
\hline $\begin{array}{l}\text { Business strategies and their } \\
\text { contexts }\end{array}$ & CRE strategies \\
Business performance & $\begin{array}{l}\text { CRE (as real estate } \\
\text { portfolio or objects) }\end{array}$ \\
Business needs & $\begin{array}{l}\text { CREM (as the CRE } \\
\text { organisation) }\end{array}$ \\
\hline
\end{tabular}


While all the cognitive objects appear relevant to CRE alignment they are different and need to be more clearly recognised as such. This distinction was not always evident in this analysis which places strategy (business and CRE) as pre-eminent concepts, as informed by strategic management theory. In business, this pre-eminence is based on strategy responding to internal and external contexts, drivers and resources, producing performance and also creating the 'needs'. In CRE, the strategy produces the CRE objects and the CREM practices. This suggests that CRE and business strategies are the primary alignment objects with the others being secondary and consequential alignment. Nevertheless, all cognitive objects need alignment, suggesting that alignment's proper conceptualisation requires all cognitive objects be included.

It was also evident that, based on the six cognitive objects, nine permutations were possible with different authors using one or more permutations of the entities to be aligned. This permutation could exist at a primary level, as in, these are the objects to align first and at a secondary level in that there were other objects from elsewhere in the hierarchy to align also. Some models presented several objects of comparable alignment importance. These findings suggest that more work is required to show the relationship between the objects in alignment processes. There is insufficient space to attend to that here and the authors are preparing a paper that does this in detail.

Finally, in attending to cognitive objects, the disparateness in the terms, while well intentioned in trying to find 'the' variable(s) to align, also provides evidence of the discipline's language imprecision. This suggests that CREM could benefit from further investigation of its semantics and cognitive objects to bring greater precision in defining its phenomena.

\section{UNDERSTANDING THE DIRECTIONALITY}

Englert's (2001) alignment definition, notes its multi-directionality - vertically between corporate and CRE strategies and horizontally across the business units and the Corporate Infrastructure Resources (CIR) (Materna, Parker 1998) concept he uses. This is also called a multi-stakeholder approach (de Jonge et al. 2009). This multi-directionality contrasts with the often-made assumption of CRE strategy just following corporate strategy. We do not disavow the importance of this. What this interpretation allows, in a comprehensive account of alignment, is for other alignment directions. Five nested directions are identifiable:

- Internal:

- Vertical:

- Top-down; and

- Bottom-up;

- Horizontal;

- Across the business units; and

- Across the CIR (Materna, Parker 1998); and

- External.

Table 5 shows the directions and the degree to which they are evident in the models.

Very many models (17 of 20-85\%) contained top-down vertical alignment corresponding to conventional wisdom that CRE strategy is linked to corporate strategy, being derived from and consistent with it. Bottom-up vertical alignment was less evident ( 6 of $20-30 \%$ ) and when evident it was more in terms of supporting the business strategy. This is positive in its correspondence with the top of the semantic hierarchy but does not match Weatherhead's (1997) argument for bottom-up alignment where corporate strategy incorporates CRE; not driven by CRE, but developed cognisant of CRE's opportunities and constraints.

Horizontal alignment was relatively rare, either within the CIR concept ( 3 of 20 ) or across the business units. Note, it is assumed here that the business units undergo their own vertical alignment with corporate strategy, as per Kaplan and Norton (2006). Horizontal alignment coordinates different business units' strategic CRE needs where, for instance, one unit's declining requirement may meet another's increase thereby avoiding two separate real estate market transactions. This direction's scarcity was surprising given the CIR concept's availability since the late 1990s.

Internal alignment was by-and-large the modelling's focus and explicitly considers current and future demands for CRE from the current and future portfolios. Depending on the result of internal alignment, external supply alignment may be required which can be achieved with existing real estate products (maybe with modification) or with completely new products. Depending on availability further iterations may be required as is the nature of the alignment process (Englert 2001; de Jonge et al. 2009).

External alignment refers to the external real estate market's satisfaction, or not, of the CRE requirements by way of availability, quality, quantity, cost, location, and technology (Osgood Jr 2004). 


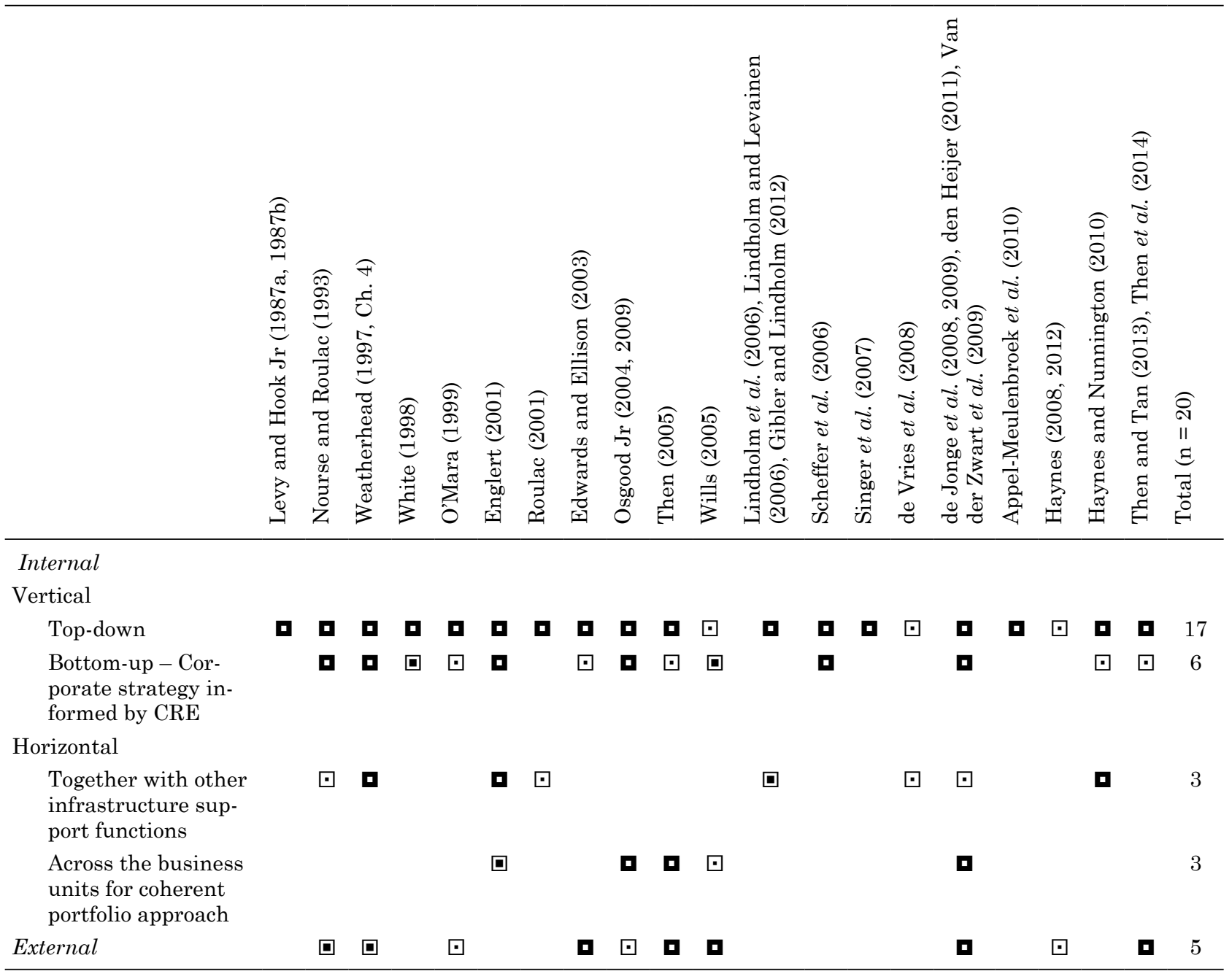

Legend: $\mathbf{\square}$ Primary alignment; $\square$ Secondary alignment; $\square$ Implied alignment.

Again, it seems obvious but is not often included (5 out of 20 (25\%) models). Various explanations exist for why alignment directions are not considered. These include: the dominance of top-downness, for horizontal alignment it could be because this has become accepted practice and therefore drops from explicit consideration; similarly for internal alignment. Perhaps external alignment is overlooked because this constitutes a given real estate expertise - market knowledge. If so, then this demonstrates this analysis' value in bringing these back into focus.

\section{UNDERSTANDING THE THEORIZING OF CRE ALIGNMENT}

Interpreting the CRE alignment models also allows understanding of how they were theorised. This is important because it points towards the nature and quality of the theory created. The aspects identified in analysis include:
- The underlying theories that defined the phenomenon (Table 2);

- Theory's origins, that is who is doing the theorising and how the theory is created;

- Theory's scientific basis; and

- How the theory is disseminated. This has implications for theory's potential take-up in practice.

Table 6 contains the results of that analysis.

This analysis showed 10 of the models (50\%) having practitioner creators and $14(70 \%)$ having researcher creators with a four models (20\%) having both. The publication dates show practitioners more evident earlier, before being largely replaced by researchers. This transition is expected as a professional discipline emerges and consolidates as a field of practice with related theorisation and contrasts with 1990s' observations of the professional CRE literature overtaking the academic literature at that time (Jud 1996; Manning, Roulac 1999). 
Table 6. Identifying the origins and scientific bases of CRE alignment models

\begin{tabular}{|c|c|c|c|c|c|c|c|c|c|c|c|c|c|c|c|c|c|c|c|c|c|c|}
\hline & 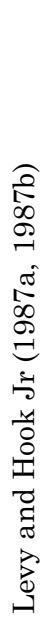 & 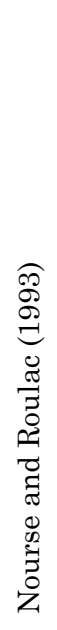 & 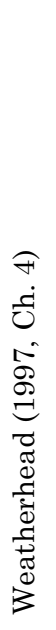 & 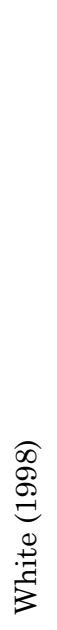 & 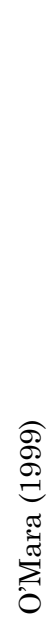 & 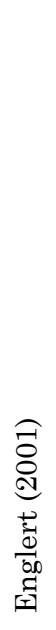 & 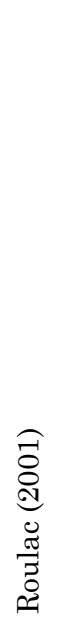 & 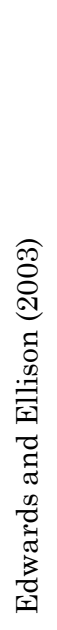 & 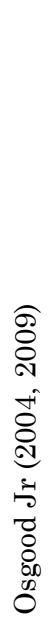 & 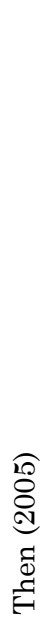 & $\begin{array}{l}\widehat{10} \\
\stackrel{0}{0} \\
\stackrel{0}{0} \\
\stackrel{0}{3}\end{array}$ & 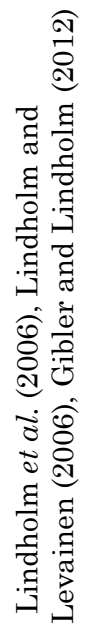 & 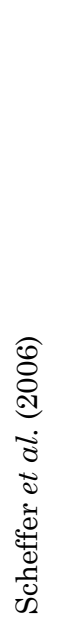 & 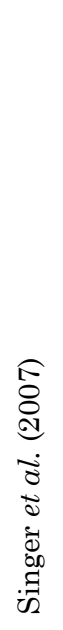 & 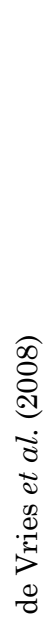 & 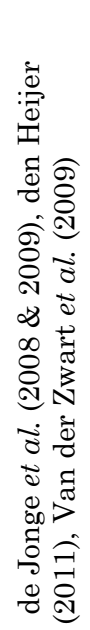 & 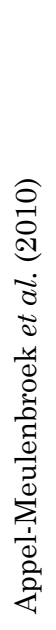 & 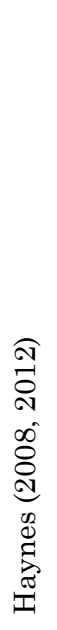 & 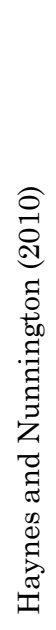 & 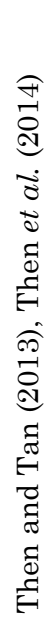 & 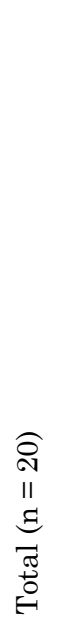 & $d^{0}$ \\
\hline \multicolumn{23}{|l|}{ Author type $(\mathrm{n}=20)$} \\
\hline Practitioner $(\mathrm{P})$ & $\mathrm{P}$ & $\mathrm{P}$ & $\mathrm{P}$ & $\mathrm{P}$ & & $\mathrm{P}$ & $\mathrm{P}$ & & $\mathrm{P}$ & & & & $\mathrm{P}^{*}$ & $\mathrm{P}^{*}$ & & & & & & $\mathrm{P}$ & 10 & 50 \\
\hline Researcher (R) & & $\mathrm{R}$ & & & $\mathrm{R}$ & & & $\mathrm{R}$ & & $\mathrm{R}$ & $\mathrm{R}$ & $\mathrm{R}$ & $\mathrm{R}$ & $\mathrm{R}$ & $\mathrm{R}$ & $\mathrm{R}$ & $\mathrm{R}$ & $\mathrm{R}$ & $\mathrm{R}$ & $\mathrm{R}$ & 14 & 70 \\
\hline \multicolumn{23}{|c|}{ Scientific basis $(n=20)$} \\
\hline $\begin{array}{l}\text { Reflective prac- } \\
\text { tice }\end{array}$ & $\mathrm{Y}$ & $\mathrm{Y}$ & $\mathrm{Y}$ & $\mathrm{Y}$ & $\mathrm{Y}$ & $\mathrm{Y}$ & $\mathrm{Y}$ & $\mathrm{Y}$ & $\mathrm{Y}$ & & & & & & & $\mathrm{Y}$ & & & $\mathrm{Y}$ & $\mathrm{Y}$ & 12 & 60 \\
\hline Empirical & & & & & $\mathrm{Y}$ & $\mathrm{Y}$ & & & $\mathrm{Y}$ & $\mathrm{Y}$ & & $\mathrm{Y}$ & $\mathrm{Y}$ & $\mathrm{Y}$ & $\mathrm{Y}$ & & $\mathrm{Y}$ & $\mathrm{Y}$ & $\mathrm{Y}$ & $\mathrm{Y}$ & 12 & 60 \\
\hline Normative & $\mathrm{Y}$ & $\mathrm{Y}$ & $\mathrm{Y}$ & $\mathrm{Y}$ & $\mathrm{Y}$ & & $\mathrm{Y}$ & $\mathrm{Y}$ & $\mathrm{Y}$ & $\mathrm{Y}$ & $\mathrm{Y}$ & $\mathrm{Y}$ & $\mathrm{Y}$ & & & $\mathrm{Y}$ & & & $\mathrm{Y}$ & & 14 & 70 \\
\hline Validation & & $\mathrm{Y}$ & & & $\mathrm{Y}$ & & & & $\mathrm{Y}$ & $\mathrm{Y}$ & & $\mathrm{Y}$ & $\mathrm{Y}$ & $\mathrm{Y}$ & $\mathrm{Y}$ & $\mathrm{Y}$ & $\mathrm{Y}$ & & $\#$ & $\mathrm{Y}$ & 11 & 55 \\
\hline \multicolumn{23}{|c|}{ Literature type $(n=20)$} \\
\hline \multicolumn{23}{|l|}{$\begin{array}{l}\text { Professionally- } \\
\text { oriented }\end{array}$} \\
\hline Report & & & & & & $\mathrm{Y}$ & & & $\mathrm{Y}$ & & & & & & & & & & & & 2 & 10 \\
\hline $\begin{array}{l}\text { Book/book chap- } \\
\text { ter }\end{array}$ & $\mathrm{Y}$ & & $\mathrm{Y}$ & & & & & & & & & & & & & & & & & & 2 & 10 \\
\hline \multicolumn{23}{|l|}{ Researcher-oriented } \\
\hline Academic journal & & $\mathrm{Y}$ & & $\mathrm{Y}$ & & & $\mathrm{Y}$ & & $\mathrm{Y}$ & $\mathrm{Y}$ & & $\mathrm{Y}$ & $\mathrm{Y}$ & $\mathrm{Y}$ & $\mathrm{Y}$ & & & $\mathrm{Y}$ & & & 10 & 50 \\
\hline Book/book chapter & & & & & $\mathrm{Y}$ & & & & & & & & & & & $\mathrm{Y}$ & & & & $\mathrm{Y}$ & 3 & 15 \\
\hline Text book & & & & & & & & $\mathrm{Y}$ & & & & & & & & $\mathrm{Y}$ & & & $\mathrm{Y}$ & & 3 & 15 \\
\hline Conference paper & & & & & & & & & & & $\mathrm{Y}$ & & & & & $\mathrm{Y}$ & $\mathrm{Y}$ & & & & 3 & 15 \\
\hline
\end{tabular}

Legend: * While recorded as practitioners in the author details the reported project was conducted as an academic project. \# Being validated at the time of writing.

Related to this is the models' scientific basis pertaining to their emergence into the body of knowledge and which represents their theory-making type. Three ways of emergence were identified:

1. From an empirical study;

2. As a result of reflective practice; and

3. As normative statements.

These are not unrelated, for instance, an empirical study may document existing norms, or empirical studies and reflections on practice could result in statements of norms. Scientific 'knowledge-making' often presumes that empirical studies are more valid knowledge creation forms. This analysis shows that just less than two-thirds (12 models - 60\%) have an empirical basis. Reflective practice is also evident at similar levels (12 models). Reflective practice is a good thing contributing to learning practitioners, and adaptive practice (after Schön 1983). However, normative statements are the most common scientific basis (14 of 20 models - 70\%). Their large presence with the inference that 'You should do alignment like this' contributes to understanding that the models' directive quality is intended to improve alignment practice. Whether and how this might be the case is challenged by the authors' survey during a CoreNet Global EMEA Summit session with about 40 professionals and a response of $60 \%$ indicating 
low practitioner awareness of the models suggesting that the models are probably not impacting on practice, at least not knowingly.

Validating models empirically occurred in just over half the models ( 11 of 20 models $-55 \%$ ). Of those not validated (9-45\%) practitioner models are most prevalent (5 of 9) though it might be expected that they might not apply the same rigour that researchers should. This analysis shows several researchers presenting non-validated models, though in some instances, like Haynes (2012), the article represents work-in-progress. Nourse and Roulac's (1993) later validation in Appel-Meulenbroek et al. (2010) is a rare instance of models' testing outside the originating author's work. More usually the author(s) test their own model, when this it is tested. This shows a reasonable scientific quality in the model-creating and that, in general, is improving with more of the recent models validated than the older ones. Also, half the models appear in academic journals having been subject to peer review making them more scientifically robust and as a result the theorisation would be deeper.

One observation that must be made about the models' theorising is that in very many instances the evidence shows that later models' articles do not refer to the earlier modelling literature, though there are some exceptions. Possible explanations for this are that:

- The author(s) think that their contribution is a genuine improvement on previous efforts (which is commendable);

- The author(s) ignore previous efforts in order to avoid comparing their own model with what has been done previously; or

- They theorise in ignorance.

The truth or not of these could not be definitively interpreted due to that lack of attention to previous alignment models. This makes it difficult to ascertain, for a single model, whether it is an improvement or not. Each model then becomes 'just' another one in isolation. The absence of reviews also supports observations about avoidance of comparison or ignorance. Whatever the explanation, it may not augur well for the field's quality of science where previous work is so clearly overlooked. This can lead to continual reinvention - which might account for the many models. It is not the only reason, as discussed below, but nevertheless shows why a holistic study of past efforts is necessary.

Few models (4 of 20-20\%) were in the professional literature - two were professional association reports and two were in books, or book chap- ters. O'Mara could have been included here given its non-academic publisher but its origins in her doctoral work allow classification as researcherbased. Similarly, Then and Tan, while written with professional readers in mind originated in their research work. Six models are in researcheroriented books or book chapters. Of these, three are clearly text books. Ten models are found in academic journal articles.

Examining models' dissemination means (literature type) reveals intentions for the models. It is obvious that the professional literature's models were intended to aid alignment practice. Presumably, their publication place would make them more accessible to practitioners, and therefore useful. The researcher-originated models were also apparently intended to be useful to practice given the normative statements' presence. The researcher models' usefulness could be directly by practitioners or less directly by being used in education. However, it is probable that researcher publications are less accessible to practitioners. They may also be considered too theoretical and less relevant to practice. Use in education may incur a lag between exposure and opportunities to apply the models in practice. With low senior practitioner awareness of the models, and therefore low utility value placed on them it is possible that those educated in the models may rarely have an opportunity to apply their learning.

\section{DISCUSSION}

This interpretive analysis set out to do two things.

- Develop an understanding of the nature of CRE alignment as a phenomenon.

- Develop understanding of how CRE alignment is theorised.

Understanding the phenomenon's nature was developed by examining multiple models of, essentially, the same phenomenon using the fact that any model imperfectly represents reality and that examining multiple representations should enable an enlarged and more complete understanding of the phenomenon to be developed. A meta-study like this can then create order in the theory currently disordered because of the multiple representations. It may not necessarily create new theory, just more refined theory. This makes this a meta-theoretical paper rather than the instrumental theory ones most evident to date. Also, examining the language and associated conceptual bases is, perhaps, a first step towards finding a common language for studies into CRE alignment. 
This study shows CRE alignment to be pluralistic and complex, being several things simultaneously. It is not possible to show CRE alignment as a singular, definitive 'thing' making it difficult to compose a concise, pithy definition. Invariably doing so would omit something of the now clearer understanding. Nevertheless, that complexity can be distilled to four distinct things, making alignment:

- A multi-valent relationship between CRE and the business with many words used to capture different values. A value hierarchy was evident suggesting that higher value words are more important in theorising and describing alignment. However, alignment is not one of these things, it is many or all of them;

- Consists of multiple forms of two distinct types - process-based and behaviour-based. Either mode of existence is about changing alignment states for the better;

- Occurs between multiple cognitive-objects, with three evident on the business and CRE sides. Strategy level objects (corporate and CRE) were pre-eminent primary alignment objects with other objects all needing alignment but consequential to the two strategies' alignment;

- Multi-directional, that is, iteratively vertically between the organisational and functional levels, horizontally across the business units and the corporate infrastructure functions, and between demand and supply. This supply may be available from the existing portfolio or sourced externally from the real estate market.

Though complex this provides a more coherent theoretical basis to dimensionalising the alignment phenomenon. This product of Traditional interpretation points towards a platonic reality derived in an Aristotelian understanding of things - models made by humans - CRE academics and practitioners. This dimensionalised phenomenon also allows conclusions that a good alignment model should conceptualise its phenomenon by:

- Using words of higher semantic value for describing the relationship;

- Being a process (most usually) but also finding behaviour in strategic mind-sets -both producing more aligned states sometimes reported in a plan;

- Aligning strategies (corporate and CRE) with other aligned cognitive objects consequential to these; and

- Including all directions.
These dimensions are not used to analyse the models because the paper's objective is developing understanding of the phenomenon. The conclusions about what makes for good alignment in a model could also be used to examine practice's confidence in their alignment. Such analyses are future research.

This analysis also provides insights into how CRE alignment is theorised both from Traditional and Hermeneutic interpretation. First, the theorisation's variety is a consequence of scientific knowledge production methods where more-or-less tightly constrained objects are required to make the task tractable. It is inevitable in such reductionism that complexity is stripped away meaning that with a complex object as the focus, as here, different representations can result.

Second, the field's natural knowledge production allows variability, not finding this especially problematic. CREM as a management sub-field, is, as Whitley (2000) classifies it, a 'fragmented adhocracy' where there is little coordination between research sites and researchers, or control in knowledge production processes (Whitley 2000, particularly Table 5). Consequently, researchers develop personal, idiosyncratic lines of research that make 'broad diffuse contributions to broad intellectual goals' (Whitley 2000). As a result, they are not necessarily dependent on others for strategic direction or research task procedures, nor are they necessarily contributing to others' work. Under these circumstances variability is normal. The argument that CREM research is a fragmented adhocracy, in CRE alignment, is problematic. The crucial evidence is the previous alignment models' treatment. By-and-large most new models overlook them, though they are findable. This seems inadequate.

Third, relates to the usefulness-driven nature of CRE alignment in the models' scientific basis, as evidenced in many normative statements. Whitley (2000) citing Stokes (1997) suggests two contrasting research goals - an 'application and use' goal, and a 'gaining fundamental understanding' goal. CRE alignment models fall into the former which has two sub-categories. The models are, by-andlarge, part of the first sub-category 'instrumental' research focused on designing 'machines', or techniques for specific use. Edison's work is an example. The models rarely fall into the second 'explanatory instrumental' research that studies underlying explanations and harnesses them into applications. Pasteur's work illustrated here.

Fourth, the models' evident variety may not be as problematic as intimated above. The vari- 
ability may be beneficial allowing different models to be applied to particular situations, though this creates new questions about which one to choose when. However, if models are designed as general explanations of the phenomenon they 'should', as a result, describe every situation, at least generally, rather than applying specifically.

There is, partially explainable by needing to control the variables in individual models, a lack of reference to the suite of cognitive objects that could and should be aligned. That many models are validated and published in peer-reviewed outlets makes for good science, notwithstanding the concerns expressed about the relationship with existing literature modelling CRE alignment. Evidence exists that some models are used in empirical studies of alignment, for example den Heijer (2011) and Appel-Meulenbroek et al. (2010). This is good despite the lack of evidence about the models' application directly into practice.

\section{CONCLUSION}

This research interpretively interrogated twenty CRE alignment models to understand CRE alignment and its theorisation. From an apparently disordered theory this analysis shows alignment to be complex and pluralistic with four dimensions, plus sub-dimensions, existing simultaneously. Though complex this represents a significant conceptual improvement in the field. From this understanding it was also possible to point towards how good alignment models should treat the four dimensions.

The phenomenon's inherent complexity poses theorisation challenges, as seen in the multiplicity of models, contributing to the previous sense of disorder. Positive and negative aspects to previous alignment theorisation were also evident. Positively, robust science through peer-review had increased over time. Negatively, model theorisation occurred too much in isolation and was constrained by simplifications required to make modelling tractable.

Though the paper sought a comprehensive understanding of alignment as a phenomenon it is also evident that more is possible in understanding the models theoretically and what makes good alignment models. One research opportunity is to understand the components that make up a complete process to achieve alignment states. A second is to understand the models' inherent types of strategising. A third, given that practitioners recognise alignment when they see it and that the models are not knowingly deployed, is the basis on which alignment is occurring as praxis rather than theorisations of what 'should' occur. These gaps offer opportunities for future CRE alignment research extending the foundation established in this paper.

\section{ACKNOWLEDGEMENTS}

We acknowledge initial funding for this project from a University of Melbourne, Faculty of Architecture, Building and Planning Early Career Research grant and colleagues of Monique Arkesteijn (prof. ir. Hans de Jonge and dr. ir. Alexander Koutamanis) who read and commented on early drafts.

\section{REFERENCES}

Appel-Meulenbroek, R.; Brown, M. G.; Ramakers, Y. 2010. Strategic alignment of corporate real estate, in Proceedings of the 17th European Real Estate Society (ERES) Conference, 23-26 June 2010, Milan, Italy.

Arkesteijn, M.; Valks, B.; Binnekamp, R.; Barendse, P.; de Jonge, H. 2015. Designing a preference-based accommodation strategy: a pilot study at Delft University of Technology, Journal of Corporate Real Estate 17: 98-121. https:/doi.org/10.1108/JCRE-12-2014-0031

Beckers, R.; Van Der Voordt, T. J. M.; Dewulf, G. 2015. Aligning corporate real estate with the corporate strategies of higher education institutions, Facilities 33: 775-793. https:/doi.org/10.1108/F-04-2014-0035

Bleicher, J. 1980. Contemporary hermeneutics: hermeneutics as method, philosophy and critque. London: Routledge and Kegan Paul.

Bon, R.; Luck, R. 1998. Annual CREMRU-JCI survey of corporate real estate management practices in Europe and North America: 1993-1997, Facilities 16: 82-92. https:/doi.org/10.1108/02632779810205594

Bon, R.; Luck, R. 1999. Annual CREMRU-JCI survey of corporate real estate practices in Europe and North America: 1993-1998, Facilities 17: 167-176. https:/doi.org/10.1108/02632779910259251

Carney, T. F. 1972. Content analysis: a technique for systematic inference from communications. London: B. T. Batsford.

David, F. R. 2013. Strategic management: a competitive advantage approach - concepts and cases. Boston: Pearson.

de Jonge, H. 1996. Toegevoegde waarde van concernhuisvesting, in NSC Conference, 15 October 1996, Nieuwegein: Arko Publishers, 66-67.

de Jonge, H.; Arkesteijn, M. H.; den Heijer, A. C.; Vande Putte, H. J. M.; de Vries, J.; Van Der Zwart, J. 2008. Corporate real estate management: designing an accommodation strategy (DAS Frame). $1^{\text {st }}$ ed. Delft, TU Delft, Faculty of Architecture, Department of Real Estate and Housing.

de Jonge, H.; Arkesteijn, M. H.; den Heijer, A. C.; Vande Putte, H. J. M.; de Vries, J. C.; Van der Zwart, J. 
2009. Corporate real estate management: designing an accommodation strategy. Delft: Technical University Delft.

de Vries, J. C.; de Jonge, H.; Van Der Voordt, T. J. M. 2008. Impact of real estate interventions on organisational performance, Journal of Corporate Real Estate 10: 208-223. https:/doi.org/10.1108/14630010810922094

den Heijer, A. C. 2011. Managing the university campus: information to support real estate decisions: $\mathrm{PhD}$ Thesis. Technical University of Delft.

Dewulf, G.; Krumm, P.; de Jonge, H. 2000. Successful corporate real estate strategies. Delft, The Netherlands, Arko.

Edwards, V.; Ellison, L. 2003. Corporate property management: aligning real estate and business strategy. Malden, MA: Blackwell Science.

Englert, J. 2001. The strategic alignment handbook: a corporate infrastructure resource (CIR) management application guide. Atlanta: IDRC Foundation.

Gibler, K. M.; Lindholm, A.-L. 2012. A test of corporate real estate strategies and operating decisions in support of core business strategies, Journal of Property Research 29: 25-48. https:/doi.org/10.1080/09599916.2011.608470

Hamel, G.; Prahalad, C. K. 1994. Competing for the future. Boston, MA: Harvard Business School Press.

Haynes, B. 2012. Corporate real estate asset management: aligned vision, Journal of Corporate Real Estate 14: 244-254.

https:/doi.org/10.1108/JCRE-10-2012-0022

Haynes, B. P. 2008. Impact of workplace connectivity on office productivity, Journal of Corporate Real Estate 10: $286-302$.

https:/doi.org/10.1108/14630010810925145

Haynes, B. P.; Nunnington, N. 2010. Corporate real estate and asset management: strategy and implementation. Oxford: EG Books.

Henderson, J. C.; Venkataraman, N. 1991. Understanding strategic alignment, Business Quarterly 55(3): 8-14.

Henderson, J. C.; Venkataraman, N. 1993. Strategic alignment: leveraging information technology for transforming organisations, IBM Systems Journal 32: 4-16. https:/doi.org/10.1147/sj.382.0472

Heywood, C. 2007. The role of affect in local government corporate real estate management: $\mathrm{PhD}$ Thesis. University of Melbourne.

Heywood, C. 2011. Approaches to aligning corporate real estate and organisational strategy, in R. AppelMeulenbroek; I. Janssen (Eds.). Proceedings of the $18^{\text {th }}$ Annual European Real Estate Society Conference, 15-18 June 2011, Eindhoven, The Netherlands.

Idenburg, P. J. 1993. Four styles of strategy development, Long Range Planning 26: 132-137. https:/doi.org/10.1016/0024-6301(93)90215-2

Joroff, M.; Louragand, M.; Lambert, S. 1993. Strategic management of the fifth resource: corporate real estate. Atlanta: IDRC.

Jud, G. D. 1996. The Journal of Real Estate Research: a ten-year review, Journal of Real Estate Research 12: 249-313.
Kaplan, R. S.; Norton, D. P. 1996. Translating strategy into action: the Balanced Scorecard. Boston: Harvard Business School Press.

Kaplan, R. S.; Norton, D. P. 2000. Having trouble with your strategy? Then map it, Harvard Business Review 78: 167-176.

Kaplan, R. S.; Norton, D. P. 2001. The strategy focussed organisation. Boston: Harvard Business School Press.

Kaplan, R. S.; Norton, D. P. 2006. Alignment: using the Balanced Scorecard to create corporate synergies. Boston: Harvard Business School Press.

Kiser, L.; Ostrom, E. 1982. The three worlds of action: a meta-theoretical synthesis of institutional approaches, in E. Ostrom (Ed.). Strategies in political inquiry. Beverly Hills: Sage.

Labovitz, G.; Rosansky, V. 1997. The power of alignment: how great companies stay centred and accomplish extraordinary things. New York: John Wiley \& Sons.

Levy, G. M.; Hook Jr, R. C. 1987a. Choosing strategic objectives, in R. A. Silverman (Ed.). Corporate real estate handbook. New York: McGraw-Hill.

Levy, G. M.; Hook Jr, R. C. 1987b. Implementing strategic objectives, in R. A. Silverman (Ed.). Corporate real estate handbook. New York: McGraw-Hill.

Lindholm, A.-L.; Gibler, K.; Levainen, K. I. 2006. Modelling the value-adding attributes of real estate to the wealth maximization of the firm, Journal of Real Estate Research 28: 445-475.

Lindholm, A.-L.; Levainen, K. I. 2006. A framework for identifying and measuring value added by corporate real estate, Journal of Corporate Real Estate 8: 3846. https:/doi.org/10.1108/14630010610664796

Manning, C.; Roulac, S. E. 1999. Corporate real estate research within the academy, Journal of Real Estate Research 17: 265-279.

Materna, R.; Parker, J. R. 1998. Corporate infrastructure resource management: an emerging source of competitive advantage. Atlanta: IDRC.

McDonagh, J.; Nichols, G. 2009. Business strategy and property strategy - how strong is the linkage?, Journal of Corporate Real Estate 11: 213-228. https:/doi.org/10.1108/14630010911006701

Miles, M. B.; Huberman, A. M. 1994. Qualitative data analysis. Thousand Oaks: Sage Publications.

Mintzberg, H. 1990. The design school: reconsidering the basic premises of strategic management, Strategic Management Journal 11: 171-195. https:/doi.org/10.1002/smj.4250110302

Mintzberg, H.; Ahlstrand, B.; Lampel, J. 1998/2007. Strategy safari. New York: The Free Press.

Mintzberg, H.; Quinn, J. B.; Ghoshal, S. 1998. The strategy process. London: Prentice Hall.

Mugeraurer, R. 1995. Interpreting environments: tradition, deconstruction, hermeneutics. Austin, TX: University of Texas Press.

Nourse, H. O.; Roulac, S. E. 1993. Linking real estate decisions to corporate strategy, Journal of Real Estate Research 8: 475-495.

Oakerson, R. J. 1982. Analysizing the commons: a framework, in W. D. Bromley (Ed.). Making the commons 
work: theory, practice and policy. San Francisco: Institite for Contemporary Studies Press.

Oakerson, R. J. 1984. A model for the analysis of common property problems, in N. R. Council (Ed.). Conference on common property resource management. 17 May 1984. Washington D.C. National Academy Press.

O’Mara, M. A. 1999. Strategy and place: managing corporate real estate and facilities for competitive advantage. New York: The Free Press.

Osgood Jr, R. T. 2004. Translating organisational strategy into real estate action: the strategy alignment model, Journal of Corporate Real Estate 6: 106-117. https:/doi.org/10.1108/14630010410812289

Osgood Jr, R. T. 2009. Survey results and practical experience with the Fortune 1000. Atlanta: CoreNet Global.

Ostrom, E. 1986. An agenda for the study of institutions, Public Choice 18: 3-25. https:/doi.org/10.1007/bf00239556

Ostrom, V. 1976. John R. Common's foundations of policy analysis, Journal of Economic Issues 10: 839-857. https:/doi.org/10.1080/00213624.1976.11503391

Patton, M. Q. 1990. Qualitative evaluation and research methods. Newbury Park, California: Sage Publications.

Porter, M. E. 1980. Competitive strategy: techniques for analysing industries and competitors. New York: Free Press.

Porter, M. E. 1985. Competitive advantage. New York: Free Press.

Porter, M. E. 1996. What is strategy?, Harvard Business Review Nov-Dec: 61-78.

Roulac, S. E. 2001. Corporate property strategy is integral to corporate business strategy, Journal of Real Estate Research 22: 129-151.

Scheffer, J. J. L.; Singer, B. P.; Van Meerwijk, M. C. C. 2006. Enhancing the contribution of corporate real estate to corporate strategy, Journal of Corporate Real Estate 8: 188-197. https:/doi.org/10.1108/14630010610714862

Schön, D. A. 1983. The reflective practitioner: how professionals think in action. New York: Basic Books.

Singer, B. P.; Bossink, B. A. G.; Vande Putte, H. J. M. 2007. Corporate real estate and competitive strategy, Journal of Corporate Real Estate 9: 25-38. https:/doi.org/10.1108/14630010710742464
Stokes, D. 1997. Pasteur's quadrant: basic science and technological innovation. Washington D.C.: Brookings Institute Press.

Swayne, L. E.; Duncan, W. J.; Ginter, P. M. 2006. Strategic management of health care organisations. Oxford: Blackwekk Publishing.

Then, D. S. S. 2005. A proactive property management model that integrates real estate provision and facilities services management, International Journal of Strategic Property Management 9: 33-42.

Then, D. S. S.; Tan, T. H.; Fonseca Santovito, R.; Jensen, P. A. 2014. Attributes of alignment of real estate and facilities management to business needs, Journal of Corporate Real Estate 16: 80-96. https:/doi.org/10.1108/JCRE-09-2013-0026

Then, D. S. S.; Tan, T. H. 2013. Facilities management and the business of managing assets. Abingdon: Routledge.

Tregoe, B. B.; Zimmerman, J. W. 1980. Top management strategy: what it is and how to make it work. New York: Simon and Schuster.

Van der Zwart, J.; Arkesteijn, M. H.; Van Der Voordt, D. J. M. 2009. Ways to study corporate real estate management in healthcare: an analytical framework, in Proceedings of the $2^{\text {nd }}$ Annual Conference of the Health and Care Infrastructure Research and Innovation Centre - Improving healthcare infrastructures through innovation, 2-3 April 2009, Brighton, UK.

Veale, P. R. 1989. Managing corporate real estate assets: current executive attitudes and prospects for an emergent management discipline, Journal of Real Estate Research 4: 1-22.

Weatherhead, M. 1997. Real estate in corporate strategy. Houndmills: Macmillan Press. https:/doi.org/10.1007/978-1-349-14024-4

White, A. D. 1998. Corporate real estate strategies: managing the delivery of optimum solutions, Journal of Corporate Real Estate 1: 64-74. https:/doi.org/10.1108/14630019910810962

Whitley, R. 2000. The intellectual and social organization of the sciences. Oxford: Oxford University Press.

Wills, P. C. 2005. Aligning corporate real estate and business strategies, in Proceedings of the $11^{\text {th }}$ Pacific Rim Real Estate Society (PRRES) Conference, 23-27 January 2005, Melbourne, Australia. 